Scientific fraud

\section{New Public Health service policy}

Washington

AFTER a delay of four years, the US Public Health Service (PHS) has inaugurated a formal policy for dealing with allegations of scientific misconduct such as fabrication and plagiarism. Scientific staff and officials of organizations receiving PHS funds must in future report alleged misconduct to designated institutional "misconduct policy officers". The new policy also requires institutions that receive its funds to certify that they have in place procedures for investigating allegations of misconduct, and to inform the funding agency when formal investigations are initiated.

The need for a formal PHS policy became apparent after a spate of widely publicized cases of fraud, plagiarism and other misconduct in biomedical research in the early 1980s, of which John Darsee's fabrication of research results was the most infamous. The effort to develop ways of dealing with allegations effectively while minimizing damage to the reputations of those unjustly accused was instigated in 1982. Congress instructed PHS to develop a policy last year.

The new policy has been developed chiefly by the Office of Extramural Research and Training of the National Institutes of Health (NIH), which has in recent years overseen NIH misconduct investigations on an ad hoc basis. The deputy director of NIH for extramural research and training, currently Dr William Raub, is "misconduct policy officer" for the whole of PHS. Fifty allegations were received by Raub's office in 1985, of which twentyfour proved substantial; the frequency of allegations has increased markedly since the early 1980s, for reasons not clearly understood.

The policy defines misconduct as either a "serious deviation" from accepted research or reporting practices, or material failure to comply with requirements such as those protecting human subjects or animals. Institutions are required to conduct thorough reviews of any allegation that is "not frivolous or unsubstantiated", preferably within 60 days, and to keep NIH informed about the investigation.

Suggested sanctions range from a simple reprimand to imposition of special reporting conditions and debarment of individuals or institutions. Criminal misconduct such as misappropriation of funds is excluded from the policy and dealt with by separate procedures.

The policy now implemented by PHS is likely to serve as a model for similar policies in other research agencies; the National Science Foundation, for one, expects to implement an almost identical policy. The Office of Management and
Budget has recently proposed requiring all federal agencies that award research grants to develop policies for debarment, necessary if debarment is to withstand a court challenge.

The detailed PHS policy guidelines, which include sections for agency personnel and for institutions that receive grants, outline procedures for conducting investigations and for determining administrative action. Individuals under investigation must always be so informed; otherwise, the fact that an investigation is in progress is restricted to those who need to know. As far as possible, informants' identities are kept secret.

Although the announcement of the PHS policy appears to have been somewhat muffled, it was approved by acting assistant secretary for health Donald MacDonald in April and came into force immediately. The policy retains "interim" status until incorporated into standard guidance documents for agency staff.

The interim policy would establish a PHS-wide "alert" system to notify awarding institutions when grant applicants are under investigation for misconduct or are subject to restrictions resulting from adjudged misconduct. Individuals flagged in the "alert" system are not necessarily precluded from receiving an award or participating in review committees; decisions are made according to circumstances.

Although NIH themselves already have an "alert" system, its extension to the whole of the Public Health Service will under the Privacy Act require publication in the Federal Register, as it entails maintaining a database referencing individuals.

Details of the responsibilities of institutions receiving funds have also yet to be published for comment before the policy can be put into force; both Federal Register notices should be published in August.

The new policy does not answer all the demands of those who have been critical of PHS's existing informal procedures. Institutions are required to inform their awarding agency of an investigation only if preliminary inquiries suggest that the allegations are serious and plausible; some contend that perceived pressure on an institution not to find evidence of wrongdoing will jeopardize impartial scrutiny. But NIH did not want the responsibility of investigating every allegation made, and after long debate decided that primary responsibility should rest with the host institution. NIH can follow up with their own investigation if the institution's appears inadequate.

Daryl Chubin of Georgia Institute of Technology, who has studied scientific misconduct for the National Science
Foundation, comments that the existence of guidelines should make it easier for those who suspect misconduct to make their allegations confidentially. But Chubin still sees conflicting pressures on institutions that have to investigate fraud; as employers, they should normally be prepared to give employees the benefit of the doubt.

Ned Feder and Walter Stewart of NIH, in an unpublished manuscript given in testimony to Congress, have supported random audits of all published research. Such random audits are conducted by the Food and Drug Administration to ensure the veracity of data it uses in making regulations, and the agency can impose sanctions on an investigator who is found to be doing careless research. PHS's policy is, however, constrained to scrutinize only the more serious allegations.

Tim Beardsley

\section{JET Britons seek to}

BRITISH fusion physicists working at the Joint European Torus (JET) near Oxford take home less than half the pay of other European nationals on the JET project, even though they have equivalent jobs. This is blatant discrimination, the European Court of Justice heard in Luxembourg last week, two-and-a-half years after the British JET staff first instructed European lawyers to take up their case.

Last December, the Court's Advocate General recommended that a subsidiary court accept the Britons' arguments, and award them back pay. However, the subsidiary court referred the case onward to full court, which heard the oral evidence last Thursday, According to the European Commission, the back pay if awarded would amount to some $10-15$ million $\mathrm{ECU}$ (European Currency Units: roughly 1 $\mathbf{E C U}=\$ 1$, or $£ 0.67$ ). Distributed among the 222 British JET staff involved, this would amount to an average windfall of

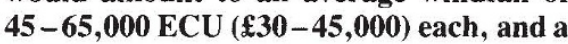
salary henceforth of twice present earnings. The Commission estimates that JET costs would rise by 2 million ECU annually, around 2 per cent of current expenditure. This would give the British an average pay rise of $£ 9,000$.

Perhaps unsurprisingly, 75 per cent of the Britons working at JET have contributed to a legal fund to pay for the case in Luxembourg, which is based on the argument that the JET statutes discriminate against British employees and so contravene the Treaty of Rome the basic legal text of the European Economic Community (EEC). EEC pays for JET through its Euratom component. The Treaty of Rome demands equal treatment of all EEC nationals, but the JET statutes, agreed (perhaps illegally, it now seems) by the European Council of Ministers in 1978, 


\section{New test facility defended}

Washington

Despite delays in construction forced on it by the courts, the United States Army has defended its plans to build a biological aerosol test facility (BATF) at the Dugway proving ground. In a report to Congress, the Army calls BATF a "small but critical facility" needed to provide adequate defence against biological weapons. But critics worry that the facility may easily be mistaken for the harbinger of a new offensive biological weapons programme, putting arms control agreements at risk.

Language inserted into last year's defence appropriations bill required the Army to respond to a set of specific questions about the planned uses of the Dug-

\section{double their pay}

have Britons employed by the United Kingdom Atomic Energy Authority on British salaries, while non-Britons (some 162 in all) are employed by Euratom on the very comfortable salaries of a European civil servant.

The European Commission is resisting any change in the JET salary arrangements, however, and an official pointed out on Monday that there were precedents. Euratom helps support a number of other European fusion research centres besides JET, though these are national (such as Britain's own laboratory at Culham, France's at Fontenay aux Roses, and West Germany's at Garching). There are a number of non-nationals ( 30 at Fontenay, 10 at Garching, but just one at Culham) who are supported at these institutions on Euratom contracts somewhat more favourable than the local, national pay scales. JET is unique, however, in having a roughly 50:50 ratio of local and Euratomsupported staff.

According to a spokesman for the British group at JET, the loyalty and commitment of the Britons to the JET project remains high, and some of the Euratom employees at the laboratory are supporting the case. The late director of the JET project, Hans-Otto Wüster, in fact first suggested the Britons seek legal advice, although he resisted that advice when it proved favourable to the Britons' case. Morale is good at JET, staff insist, and the case is being pursued "without passion". The European Commission hopes for a court decision by the end of this year. Meanwhile, the British at JET are waiting for the recommendations of the new Advocate General appointed to the case; unfortunately for them, the first, who found in their favour in the lower court, has now retired.

Robert Walgate way facility. In its written response, delivered to Congress earlier this month, the Army states that "the United States cannot defend itself adequately against conventional biological warfare agents", making increased defensive efforts crucial. Two factors convince the Army that greater vigilance to the threat of biological warfare is necessary. The United States still maintains that yellow rain in SouthEast Asia is evidence of Soviet use of biological weapons in violation of the 1972 biological weapons convention

In addition, new biotechnologies provide cheap and easy methods for production of biological agents that can be used as weapons. BATF is designed to test defensive equipment against a variety of potential biological agents. Despite the fact that Army plans call for a biosafety level 4 facility, the level traditionally associated with recombinant DNA experiments involving virulent agents, the Army has no plans to test genetically engineered material in BATF.

But critics feel the Army's own arguments will force it to resort to testing recombinant DNA organisms. Barbara Rosenberg, a molecular biologist at the Sloan Kettering Institute in Rye, New York, and a member of the committee on the military use of biological research, argues that developing a defence against the many agents formed by recombinant DNA techniques will require similar technology. Indeed, the Army report does not permanently rule out such activities.

The Biological Weapons Convention prohibits signatories from developing, producing or maintaining stockpiles of biological weapons. The Army maintains that BATF does not violate the convention because research on biological agents for "prophylactic, protective or other peaceful purposes" is permitted by the treaty. But critics point out that toxic agents used for testing could quickly be transformed into offensive stockpiles. Possessing such a capability only heightens uncertainty about US intentions, says Rosenberg.

The Dugway facility has faced problems since it was proposed in 1984. At first, the project was held up by Senator Jim Sasser (see Nature 312, 189; 1984). After Sasser's objections were resolved, Jeremy Rifkin successfully thwarted Army plans by convincing a federal judge that the Army had not made an adequate environmental assessment for its facility. The Army has now commissioned a complete environmental impact statement due to be completed at the end of this year. But even an acceptable impact statement may not persuade the court to lift its injunction blocking construction of BATF. Joseph Palca
Chernobyl

\section{Eastern bloc reactions}

THE chief inspector of the Czechoslovak Atomic Commission, Jiri Beranek, has called for a re-evaluation of all nuclear safety measures, on both a national and an international level. Interviewed on Prague radio, Beranek stressed the need for a longterm study of possible chemical reactions within reactors that would lead to the generation of hydrogen, the presence of combustible material in reactors, and the reliability of the human factor

The first two points clearly relate to the Chernobyl disaster. Although the Soviet government's special commission on Chernobyl has not yet reported, Soviet experts have already accepted a scenario in which a surge of power led to the production of steam, which reacted with the zirconium fuel-cans to produce hydrogen. Whether human error was directly involved at Chernobyl is unclear. In midMay, the Soviet media made brief mention of an "experiment" being in progress at the time of the accident, which could mean that someone tried some unorthodox method of dealing with the reactor which was already causing problems.

Beranek's concern for increased nuclear safety coupled with a firm commitment to nuclear power is typical of Comecon officials - although most of them. privately, have a good store of "black" post-Chernobyl jokes. In Poland, where some 300 inhabitants of the Bialystok area signed a petition calling for a halt to construction of the country's first nuclear plant at Zarnowiec, the official reply was that a future without nuclear power would put Poland back in the dark ages.

In Hungary even the dissident ecological "Danube Circle" has refused to condemn nuclear power, which it sees as less threatening than the controversial Gabeikovo-Nagymaros hydroelectric dam. And the Soviet Union itself, of course, is still committed to an energy policy based on the "accelerated growth of nulcear power". which, according to the current five-year plan, should produce an output of $390,000 \mathrm{GW}$ in 1990 (against $167,000 \mathrm{GW}$ in 1985).

It is only the Soviet Union's non-aligned and neutral neighbours that changed their energy strategy in the aftermath of Chernobyl. Yugoslavia, which already had a vocal antinuclear lobby, has postponed any decision on further nuclear power plants "until the long-term programme for the development of the energy industry has been adopted", and has decided to concentrate on energy conservation and hydroelectric power. And Finland has likewise dropped plans for a fifth nuclear power plant.

Vera Rich 